8

\title{
Visualizing Boundaries and Embodying Conflicts: Lessons Learned From a Theatrical Professional Development Program
}

\author{
Amrit Mundy \& Judy Chan \\ University of British Columbia
}

In the 2011-2012 academic year, the Organizational Development and Learning unit and the Centre for Teaching, Learning and Technology at the University of British Columbia co-developed an interactive theatre project, Conflict Theatre, to engage in discussion around conflict with our audience and to allow us to explore, engage with, and build resilience around workplace conflict in a University staff development context. The objectives of this essay are to narrate our thinking and experiences in developing and performing the interactive theatre sketches, and to share personal reflections from a range of Conflict Theatre participants.

\section{Introduction}

B uilding resilience around, and finding ways to engage with, conflict is relevant and necessary across all professional, personal, teaching, and learning spaces (Hughes, Huston, \& Stein, 2010). At the University of British Columbia (UBC), mutual respect, equity, and intercultural understanding are among the top priorities, and we think that finding constructive ways of engaging with conflict, and building resilience around it, is a way to move these priorities forward. In 2009, an interactive theatre program was established to promote awareness of cultural, privilege, power, oppression, diversity, and personality boundaries in classroom settings at UBC (Harlap \& Chan, 2010). In 2011, a group of managers and staff drew on this and created Conflict Theatre to extend an awareness of the complexities and challenges that arise in our university's diverse workplace environments. In this essay, we provide some of the theoretical background underlying Conflict Theatre, describe the development and performance of this Theatre, share our collected experiences and identify how we intend to move forward.

\section{Theoretical Background}

Theatre is an affective and effective tool to raise awareness, foster individual empowerment, and promote engagement. Interactive theatre is particularly powerful as it requires participants to be active in exploring problems, creating dialogues and developing possible solutions (Gibb, 2004). Interactive theatre offers valuable experiential learning opportunities in a range of educational settings ranging 
from youth education to management development (Beirne \& Knight, 2007; Coopey, 1998; Day, 2002; Gibb, 2004; Elm \& Taylor, 2010; Nissley, Taylor, \& Houden, 2004).

We chose to follow the work of David Diamond (2007), as outlined in his Theatre for Living annual workshops and book. Diamond's work originally grew from Augusto Boal's work on Theatre of the Oppressed (1985) and Paulo Freire's Pedagogy of the Oppressed (1970). Diamond (2007) suggests that the distinction between the oppressor and the oppressed as described by Boal (1985) is an artificial construct and polarizes "living communities into good guys and bad guys" (p. 22). Instead, Diamond (2007) recognizes communities as "integrated, and perhaps dysfunctional organism[s] that [are] struggling to resolve difficult issues" (p.24). In line with this, we have increasingly talked about encouraging and building conflict resilience in the workplace, and the importance of conflict engagement rather than conflict resolution (Campbell, 2011).

A second idea within Theatre for Living that Conflict Theatre borrows strongly from is that theatre is a vehicle for living communities to tell their stories and if communities are unable to do so they get sick, become fragmented, and certainly lose "their ability to collectively tell their stories" (Diamond, 2007, p. 19). Related to this but at a more individual level, Rosenwald and Ochberg (1992) argue that personal stories and narrative are "the means by which identities may be fashioned" (as cited in Clarke, 2001, p.1). Furthermore, Rossiter (1999) points out that "we understand the world and our experiences narratively, so also do we understand and construct the self as narrative [and while this] construction is complex and ongoing, the central task of the personal narrative is the creation of coherence" (as cited in Clarke, 2001, p.5).

A third idea discussed by Diamond, that shows up strongly in our work with Conflict Theatre is the systems thinking perspective and the value of creating disturbance. A Joker is an important element of a Theatre for Living project, and his or her role is to create a very safe workshop space for participants as well as "to create disturbances by giving a voice to people who would normally not be heard, or by enabling individuals to manifest conflicting voices. These disturbances then set in motion the group dynamics that lead to change" (Diamond, 2007, p. 16). Diamond (2007) suggests that "one can never direct a living system; one can only disturb it" (p. 16). He introduces a framework where difficulties can be recognized through telling stories and building scripts; resilience and engagement within a system can be approached by allowing disturbance.

The Conflict Theatre was set in motion in the following context. The Organizational Development and Learning (ODL) unit at UBC initiated Managing at UBC, a program offered to new managers at the university, in 2007. The Managing at UBC program comprises of 32 learning modules, including one module on team building. Recognizing that conflict is inevitable while building high performing teams, ODL felt that there is a need to support university managers in engaging, and developing resilience, with conflict. In adapting the Theatre for Living framework described by Diamond (2007), we hoped to develop and perform interactive theatre with participants and alumni of the Managing at UBC program. We see this as one tool towards developing conflict resilience while bringing awareness to existing, though invisible, boundaries and building strong teams in our very diverse work environment.

In our work with Conflict Theatre, we followed two main steps: script development and performance.

\section{Development of Conflict Theatre: Telling Our Stories and Script Building}

Telling stories is an integral part of Conflict Theatre as we understand ourselves and our environments through personal stories and narratives (Clark, 2001; Diamond, 2007). A major component of the Conflict Theatre is to create a safe space where challenging and resonant conflict stories can be exchanged, explored and woven into a collective script. In June 2011, we sent an invitation to all participants and alumni of Managing at $U B C$ to join the Conflict Theatre program. As a result, 15 staff and managers representing six academic and service units at the university volunteered and formed the Conflict Theatre Troupe.

The Troupe met for eight weeks, for three hours each week, during the summer of 2011 and engaged in a series of team building activities to facilitate a safe exploration of our personal stories related to both personal and workplace conflict. As listed in Table 1, Troupe members also engaged in a series of theatrical exercises to weave our stories together for the development of three scripts, and rehearsed interactive theatre through 
a number of improvisation exercises as described by Diamond (2007).

By the end of Week 6, the Troupe developed three 5-minute scripts. The Troupe chose one script that resonated with them the most and used our collective workplace experience to further develop the script and the characters. The script we chose consists of four characters: a new manager, a new staff member in a junior position, and two experienced staff members. The script showcases a weekly staff meeting during which there are a series of tense moments that include vacation scheduling priority, distribution of work, hiring policy, and a discussion of what makes a team. The meeting does not go as anticipated, resulting in a staff member storming out of the meeting.

While the lines of the script are set, it is created to allow each Troupe member to bring their own experience to their character. For instance, the character of the manager has been played as a seasoned manager recently

Table 1

A Conflict Theatre Workshop Synopsis ${ }^{1}$

\begin{tabular}{|c|c|c|c|}
\hline Week & Introduction & Exercises & Closing \\
\hline $\begin{array}{l}\text { 1: What does conflict mean } \\
\text { to you? }\end{array}$ & $\begin{array}{l}\text { Welcome, questions, } \\
\text { expectations, agreements, } \\
\text { and introduction of the } \\
\text { Theatre of the Oppressed }\end{array}$ & $\begin{array}{l}\text { Pulsing Circle, Name Game, } \\
\text { Cover the Space, Human } \\
\text { Knot, Push-Pull, Complete the } \\
\text { Image, discussion on conflict, } \\
\text { Duelling Images }\end{array}$ & $\begin{array}{l}\text { Debrief, questions and } \\
\text { answers, administrative } \\
\text { reminders, Massage Circle }\end{array}$ \\
\hline $\begin{array}{l}\text { 2: Team and Resilience in } \\
\text { Conflict }\end{array}$ & $\begin{array}{l}\text { More on Theatre of the } \\
\text { Oppressed, Relaxation and } \\
\text { Breathing, Daoist Meditation }\end{array}$ & $\begin{array}{l}\text { Name Game, Fear-Protector, } \\
\text { Blind Cars, Columbian } \\
\text { Hypnosis, Pulling-in-Partners } \\
\text { and Pulling-in-Groups }\end{array}$ & Reflections and Comments \\
\hline $\begin{array}{l}\text { 3: Power Dynamics and } \\
\text { Struggles, Equity, and } \\
\text { Diversity }\end{array}$ & $\begin{array}{l}\text { Breathing and Voice } \\
\text { Exploration }\end{array}$ & $\begin{array}{l}\text { The Market Place, Improv } \\
\text { Storytelling, Faint by } \\
\text { Numbers, Power Shuffle, } \\
\text { Siren's Call, Collective Short } \\
\text { Performance on Shared } \\
\text { Personal Conflicts }\end{array}$ & Massage Circle \\
\hline $\begin{array}{l}\text { 4: Stress Triggers: Flight or } \\
\text { Fight }\end{array}$ & $\begin{array}{l}\text { Introduction to Stress } \\
\text { Triggers and Flight and Fight }\end{array}$ & $\begin{array}{l}\text { Improv Storytelling, Freeze } \\
\text { Tag, Intelligent Clay, The } \\
\text { Three Irish Duels, Columbia } \\
\text { Hypnosis Forum }\end{array}$ & $\begin{array}{l}\text { Conflict Flipchart Preparation } \\
\text { on Conflict; Pulsing Circle }\end{array}$ \\
\hline $\begin{array}{l}\text { 5: Image Creation and Play } \\
\text { Building }\end{array}$ & Bradford Duelling Images & Magnetic Image & $\begin{array}{l}\text { Live Orchestra; Massage } \\
\text { Circle }\end{array}$ \\
\hline 6: Collective Stories & Forum Play; Workplace Issues & $\begin{array}{l}\text { Clap Exchanges, Creating } \\
\text { Collective Play in Small } \\
\text { Groups }\end{array}$ & Reflection \\
\hline $\begin{array}{l}\text { 7: Character Development; } \\
\text { Owning the Conflict; Stress } \\
\text { Triggers }\end{array}$ & Improv Games Main & $\begin{array}{l}\text { Developing Core Play, } \\
\text { Collective Directing, Hot } \\
\text { Seat, Fears-Desires-Secret } \\
\text { Thoughts, Improvised-Rituals, } \\
\text { Rehearsal, Brief Interventions }\end{array}$ & $\begin{array}{l}\text { Reflection; Feeling-Off-the- } \\
\text { Skin }\end{array}$ \\
\hline $\begin{array}{l}\text { 8: Rehearsal; Owning the } \\
\text { Characters }\end{array}$ & $\begin{array}{l}\text { Trust Game; Push-Pull } \\
\text { Balance }\end{array}$ & $\begin{array}{l}\text { Intervention Rehearsals, } \\
\text { Staging the Italian, Faster- } \\
\text { Louder, Deaf Audience }\end{array}$ & Pulsing Circle \\
\hline 9: Interactive Performance & Introduction; Performance & Interactive Theatre & Applaud the Audience \\
\hline
\end{tabular}

\footnotetext{
${ }^{1}$ Details of each game and exercise can be found in Boal (2002) and Diamond (2007).
} 
hired from another department as well as a fresh business degree graduate with little experience in the University setting. While the characters can be played by different actors/actresses at each performance, it is essential that the actors and actresses recognize, and are able to personalize, the struggles of their character.

\section{Performance of Conflict Theatre}

We performed Conflict Theatre twice in 2011: first in August for approximately 25 university staff and managers, and again in October for an audience of 75 . The performance follows the forum theatre format as outlined by David Diamond (2007) in his work with Theatre for Living. The script is first performed once. A Joker then invites members of the audience to come on stage and replace one of the characters whose struggle they recognize, i.e., audience members are invited to be a 'spect-actor.' The spect-actor then has the opportunity to try out a strategy in response to some aspect of the conflict they see on stage (that is, to try an 'intervention'); other actors/actresses on stage improvise in response to the spect-actor's actions. At the end of each intervention, the Joker seeks the internal thoughts of each character on stage in response to the intervention to gain insight into how it worked for them. While the spect-actor gains the most direct experience through embodying the struggling character, the rest of the audience is able to visualize how other characters reacted to the attempted strategy.

\section{Telling Stories, Systems Perspective, and Creating Disturbance}

While Conflict Theatre used personal narrative as a basis for the final sketches, our performances provided additional safe spaces for spect-actors to tell, re-tell, change, and interrupt their personal narratives and social culture on stage. Different narratives and reactions were surfaced during each performance and provided opportunities for individual and community narratives to be deepened, broadened, and to recreate coherence in our thinking based on what we observed and experienced (Hermans, 1997, as cited in Clark, 2001). While individual actors and spectactors had the opportunity to fashion and refashion their identities in conflict situations (Clark, 2001) and build resilience around the conflicts they engage in or observe on stage, this experience also allowed us to reformulate the conflict and develop a cohesive community story around our areas of conflict (Clark, 2001; Diamond, 2007).

As the boundaries became more visible after witnessing each intervention and hearing the actors' internal thoughts, audiences were given more opportunities to act out their ideas and strategies to 're-hearse' different responses to the conflict, and to see how they may land. These interventions and conflict 'rehearsals' had the potential to create disturbance and generate changes in our living and working system. Conflict is very much a part of every reality; Conflict Theatre has the potential to support a culture of constructive conflict engagement and resilience among managers at UBC.

\section{Conflict Theatre Feedback and Next Steps}

Annotated feedback gathered from audiences at our August and October 2011 performances suggest that Conflict Theatre was able to meet its intended purposes: to extend an awareness of the nuanced complexities, challenges, and boundaries that exist in diverse work environments at the university, and consider that there are different ways to engage with conflict. The following comments illustrate that awareness was promoted:

Made me think about the issues raised.

Seeing how other people struggle [in real life].

Appreciated hearing the [characters'] points of view.

Many also commented on the range of strategies tried during the performances:

Different approaches to solve problems were presented.

Experiencing different techniques in team managing.

Highlighting the importance of understanding staff motivation. 
Overall, audience members found participating in an interactive theatre a powerful learning experience:
A live performance is more interesting than listening to a slide presentation. Glad participation [on stage] wasn't mandatory [to everyone].
Today was one of the most interesting and compelling management/ leadership training initiatives I've seen presented at [the University]... The faces in the room were so engrossed.

Though we have gathered this preliminary feedback about the effectiveness of Conflict Theatre, we would like to find out in greater depth how it meets its intended purposes. We are interested in exploring the following questions: What do participants gain or learn from being part of this affective process? How memorable was the learning experience, and did the learning 'stick'? How do participants shift their personal or community stories around specific types of conflict they explore during the workshop or the performance? What are the differences in ways they analyze the complexities and challenges of these specific conflicts before and after they engage in Conflict Theatre? Had they employed different engagement strategies as a result of the interactive theatre?

Ourintention is to collect data to help usunderstand the value of Conflict Theatre for our participants and use this data to guide us in further developing the Conflict Theatre in a useful, responsive way (Gall, Gall, \& Borg, 2006). We plan to collect survey data immediately before and after our future performances and follow-up with semi-structured interviews with those audience members willing to participant. Semi-structured interviews will also be carried out with Troupe members to understand from their perspective how their participation in the eight-week long workshop shifted their personal narratives and ways of engaging with and analyzing conflict.

\section{Summary}

We intend to continue to offer Conflict Theatre to staff and other interested units at the university. As well, findings from our work are useful to develop evidencebased staff development teaching and learning practices.
Since conflict is inevitable in our working, teaching and learning roles, we believe that engaging conflict through interactive theatre could also be useful in other organizations beyond our institution.

\section{References}

Beirne, M. \& Knight, S. (2007). From community theatre to critical management studies: A dramatic contribution to reflective learning? Management Learning, 38 (5), 591-611.

Boal, A. (1985). Theatre of the oppressed. New York: Theatre Communications Group.

Boal, A. (2002). Games for actors and non-actors. London: Routledge.

Campbell, S. (2011, November) Respect in the workplace. Workshop presented at the University of British Columbia for Human Resources Advisors, Equity and Faculty Relation, Vancouver, BC.

Clark, C. (2001). Off the beaten path: Some creative approaches to adult learning. New Directions for Adult and Continuing Education, 89, 83-91. Retrieved from http://search.ebscohost.com/ login. aspx?direct=true \&db=ehh\&AN=9178892 \&site=ehost-live

Coopey, J. (1998). Learning to trust and trusting to learn: A role for radical theatre. Management Learning, 29, 365-382.

Day, L. (2002). 'Putting yourself in other people's shoes': The use of forum theatre to explore refugee and homeless issues in schools. Journal of Moral Education, 31, 21-34. Retrieved from http:// dx.doi.org/10.1080/03057240120111418

Diamond, D. (2007). Theatre for living: The art and science of community based dialogue. Victoria, BC: Trafford Publishing.

Elm, D.R. \& Taylor, S.S. (2010). Representing wholeness: Learning via theatrical productions. Journal of Management Inquiry, 19(2), 127-136. 
Freire, P. (1970). Pedagogy of the oppressed. New York: Herder and Herder.

Gall, M.D., Gall, J.P., \& Borg, W. R. (2006). Educational research (8th ed.) White Plain, NY:

Pearson Education.

Gibb, S. (2004). Arts-based training in management development: The use of improvisational theatre. Journal of Management Development, 23(8), 741-750.

Harlap, Y. \& Chan, J. (2010, February). TAG Living Lab: Using interactive theatre to walk the talk of educational equity. Workshop presented at the Educational Developers Caucus of the Society for Teaching and Learning in Higher Education Annual Winter Conference, Kamloops, BC.

Hughes, B., Huston, T., \& Stein, J. (2010). Using case studies to help faculty navigate difficult classroom moments. College Teaching, 59(1), 7-12.

Nissley, N., Taylor, S.S., \& Houden, L. (2004). The politics of performance in organizational theatrebased training and interventions. Organization Studies, 25, 817-839.

Rosenwald, G.C. \& Ochberg, R. L. (1992). Storied lives: The cultural politics of interpretation. New Haven: Yale University Press.

\section{Biographies}

Amrit Mundy is an Instructional Designer with Organizational Development \& Learning and associated with the Centre for Teaching, Learning, and Technology. She is presently designing online materials for the Managing @ UBC program and the Academic Leadership Development Program pilot. She has a Master's degree in Education Technology and a background in postsecondary course design, teaching and student learning.

Judy Chan is an Educational Developer at the Centre for Teaching, Learning and Technology, University of British Columbia. Judy co-developed an interactive theatre program to address intercultural understanding and power relationships in classrooms. 


\section{Appendix}

Identities and roles of participants in Conflict Theatre, in chronological order of appearance in the Conflict Theatre program:

Facilitator: The person who developed and led the series of eight weekly workshops.

Troupe Members: The 15 members who participated in eight weekly workshops. Their personal narratives form the foundation of the scripts. One of the authors of this essay was a Troupe Member.

Actors and Actresses: Troupe members who performed and improvised at either the August or the October 2011 performances.

Joker: The person who 'facilitated' the interactive performance. The Joker of the August 2011 performance was the same person who facilitated the workshops; the Joker of the October 2011 performance was a Troupe Member and one of the authors of this essay.

Audience: People watching the performances in August and October 2011; they were mostly members and alumni of the Managing @ UBC program.

Spect-actors: Strictly speaking, all audience watching the performances became spect-actors after some warmup exercises. For the purpose of this essay, spect-actors were members of the audience who intervened and created disturbance on stage. 